\title{
Keberanian Mengambil Risiko Bisnis pada Mahasiswa Ekonomi dan Bisnis
}

\author{
(Courage to Take Business Risks in Economics and Business Students)
}

\author{
Oleh: \\ Anna Wulandari'; Siti Awaliyati Deliabilda² \\ anna.wulandari@pelitabangsa.ac.id; sadeliabilda@gmail.com ${ }^{2}$ \\ FEBIS Universitas Pelita Bangsa ${ }^{1}$; Prodi MM Universitas Pelita Bangsa ${ }^{2}$
}

\begin{abstract}
ABSTRAK
Keberanian mengambil risiko diperlukan oleh setiap pelaku usaha tetapi memiliki tingkat yang berbeda. Penelitian ini berupaya untuk menguji perbedaan keberanian mengambil risiko para mahasiswa berdasar jenis kelamin, latar belakang keluarga dan pengetahuan wirausaha. Data penelitian diperoleh dari hasil kuesioner yang diberikan oleh 237 mahasiswa Ekonomi Bisnis Universitas Pelita Bangsa yang juga pelaku bisnis. Pengujian dilakukan dengan metode independent sampel t test dan One-way ANOVA. Hasil penelitian menunjukkan terdapat perbedaan keberanian mengambil risiko berdasarkan jenis kelamin. Tidak terdapat perbedaan keberanian mengambil risiko berdasarkan latar belakang keluarga dan pengetahuan wirausaha.
\end{abstract}

Kata kunci:

Risiko, jenis kelamin, latar belakang keluarga, pengetahuan wirausaha

\begin{abstract}
The courage to take risks is required by every business actor but at different levels. This study seeks to examine differences in students' risk-taking courage based on gender, family background, and entrepreneurial knowledge. The research data were obtained from the results of a questionnaire given by 237 Business Economics students at Pelita Bangsa University who were also business people. Tests were carried out using the independent sample t-test and One-way ANOVA methods. The results showed that there were differences in risk-taking based on gender. There is no difference in the courage to take risks based on family background and entrepreneurial knowledge.
\end{abstract}

Keywords:

Risk, gender, family background, entrepreneurial knowledge

Submit: 28 Dec 2020

Review: 29 Dec 2020

Accept: 30 Dec 2020

Publish: 31 Dec 2020 


\section{PENDAHULUAN}

Kewirausahaan telah menjadi fokus diskusi di dunia bisnis dan akademis. Kewirausahaan merupakan pendorong pertumbuhan ekonomi. Peran pengusaha dalam bidang ekonomi adalah membuka lapangan kerja sehingga dapat meningkatkan taraf hidup dan kesejahteraan masyarakat. Semakin banyak jumlah pengusaha, maka semakin banyak masyarakat yang dapat bekerja dan memperoleh penghasilan. Dengan jumlah pengangguran dan pemutusan hubungan kerja di Indonesia yang semakin tinggi akibat pandemi Covid-19, maka peran pengusaha dapat mengurangi tingkat pengangguran dan kemiskinan. Kewirausahaan dapat menjadi perangsang dalam pertumbuhan ekonomi, inovasi, pekerjaan dan kreasi usaha (Afifah, 2018)

Peran pengusaha dalam bidang sosial adalah mengurangi kriminalitas karena orang yang berpenghasilan dan dapat memenuhi kebutuhan hidupnya cenderung tidak akan melakukan tindakan kriminal. Pengusaha-pengusaha besar juga memberikan bantuan sosial yang sering disebut dengan tanggung jawab sosial perusahaan atau CSR (corporate social responsibility). Pada masa pandemi Covid19 saat ini, banyak perusahaan yang memberikan kontribusi nyata berupa bantuan alat pelindung diri bagi tenaga kesehatan, resporator, masker dan handsanitiser bagi karyawan dan masyarakat sekitar.

Peran pengusaha dalam bidang budaya adalah menumbuhkan ide baru yang diimplementasikan dalam inovasi yang memanfaatkan teknologi artificial intelligence (kecerdasan buatan), pengembangan produk, pengembangan pasar. Selain sifat inovatif, seorang pengusaha juga memiliki kemampuan melihat peluang bisnis dan berani mengambil risiko yang realisitis dan terukur untuk mewujudkan peluang tersebut menjadi nyata. Keberanian mengambil risiko merupakan ciri utama yang membedakan pengusaha dengan karyawan.

Menyadari besarnya peran pengusaha bagi perekonomian, kebudayaan dan kesejahteraan sosial, maka banyak organisasi pendidikan yang memasukkan unsur wirausaha di dalam kurikulum pembelajaran. Pendidikan kewirausahaa merupakan salah satu faktor yang membantu kaum muda untuk memahami dan menumbuhkan sikap kewirausahaan. Sikap dan pengetahuan tentang kewirausahaan ketika masih duduk di bangku sekolah/kuliah dapat membentuk kecenderungan mereka untuk memulai bisnis sendiri di masa depan (Wang \& Wong, 2004).

Akan tetapi, jumlah pengusaha di Indonesia masih jauh tertinggal dibandingkan negara Asean lainnya. Jumlah pengusaha di Singapura sebanyak $7 \%$ dari populasi, Malaysia 6\% dari populasi, Thailand 5\% dari populasi, Indonesia hanya dibawah 3\% dari populasi (https://ekbis.sindonews.com). Akan tetapi, dilihat dari jumlah perusahaan rintisan berbasis teknologi (startup) yang bermunculan bermunculan di Indonesia semakin banyak. Pada bulan November 2020, dirilis data jumlah startup di dunia yang menempatkan Indonesia pada urutan ke-lima dengan jumlah 2.195 startup. Menurut

https:/ / www.goodnewsfromindonesia.id sepuluh besar negara dengan jumlah startup terbanyak yaitu Amerika Serikat (65.910), India (8.504), Inggris (5.418), Kanada (2.728), Indonesia (2.195), Jerman (2.137), Australia (1.653), Prancis (1.484), Spanyol (1.312), Brasil (1.144). 
Dengan didukung oleh perkembangan teknologi digital, maka semakin banyak startup yang bermunculan. Saat ini Indonesia memiliki satu decacorn (Gojek) dan empat unicorn (Tokopedia, Traveloka, OVO, dan Bukalapak). Gojek memiliki valuasi perusahaan US\$ 11 miliar, Tokopedia US\$ 7 miliar, Traveloka US\$ 4,5 miliar, OVO US\$ 2,9 miliar, dan Bukalapak US\$ 2,5 miliar (https://investor.id). Kehadiran startup ini mampu mempercepat kesempatan ekonomi digital di Indonesia.

Online marketplace seperti Tokopedia, Shopee, JD.ID, dan Lazada merupakan kanal yang memfasilitasi transaksi jual beli online. Kehadiran online marketplace mendorong semakin berkembangnya minat berwirausaha masyarakat Indonesia. Berdasarlam data GlobalWebIndex, Indonesia merupakan negara dengan tingkat adopsi e-commerce tertinggi di dunia pada tahun 2019, dimana 90 persen pengguna internet di Indonesia yang berusia 16 hingga 64 tahun, pernah melakukan pembelian barang dan jasa secara online. Terbukti dari kampanye Hari belanja online nasional (Harbolnas) 12.12 pada bulan Desember 2020 yang menunjukkan peningkatan transaksi ecommerce yang signifikan dari wilayahwilayah di luar Pulau Jawa, seperti Bengkulu, Nusa Tenggara Barat, dan Papua (https:/ / www.cnnindonesia.com).

Dengan melihat perkembangan jumlah startup yang menggembirakan, tetapi bila dibandingkan dengan persentase keseluruhan populasi masih jauh tertinggal dibandingkan negara Asean lain. Dengan jumlah penduduk di Indonesia 260 juta jiwa, maka masih dibutuhkan 4 juta pengusaha baru untuk mendorong penguatan struktur ekonomi (https://kemenperin.go.id). Hal ini menggelitik untuk melakukan penelitian mengenai potensi keberanian mahasiswa dalam mengambil risiko bisnis. Ciri pengusaha adalah individu yang kreatif dan berani mengambil risiko, maka dapat dikatakan bahwa keberanian mahasiswa mengambil risiko bisnis menunjukkan sikap mereka terhadap potensi kewirausahaan mereka di masa yang akan datang.

Tujuan penelitian ini adalah untuk menguji tingkat ketertarikan mahasiswa fakultas ekonomi dan bisnis untuk berkecimpung di bidang kewirausahaan atau niat berwirausaha yang diukur dari seberapa besar keberanian mahasiswa dalam mengambil risiko bisnis (Afifah, 2018). Semakin tinggi tingkat keberanian mengambil risiko, maka semakin besar minat kewirausahaannya. Tinggi rendahnya minat berwirausaha akan dijelaskan lebih lanjut berdasarkan faktor internal yaitu jenis kelamin, pengetahuan tentang bisnis, pendapatan keluarga, dan faktor eksternal yaitu pengalaman keluarga dalam berwirausaha dan lingkungan sosial tempat mereka dibesarkan. Penelitian ini juga merangkum jenis usaha yang diminati oleh mahasiswa.

\section{METODE PENELITIAN}

\section{Sampel Penelitian}

Penelitian dilakukan selama bulan Desember 2020 dengan menyebarkan kuesioner. Responden penelitian adalah mahasiswa Program Studi Ekonomi Bisnis Fakultas Ekonomi Bisnis dan Ilmu Sosial Universitas Pelita Bangsa yang sekaligus pelaku bisnis. Kuesioner disebarkan secara online menggunakan Google Form. Link pengisian kuesioner disebarluaskan melalui media sosial (WA, Facebook, Instagram). Data kuesioner dari google form yang terisi sebanyak 237. 
Pengembangan Model/Desain Penelitian Keberanian Mengambil Risiko Bisnis

Wirausahawan adalah seseorang yang menciptakan bisnis baru dengan mengambil resiko atau ketidakpastian demi memperoleh laba, manfaat dan pertumbuhan, melalui identifikasi peluang dan kesempatan yang ada serta memanfaatkan sumberdaya yang diperlukan. Risiko bagi wirausahawan merupakan kombinasi probabilitas suatu kejadian dengan konsekuensi atau akibat yang dapat menyebabkan kerugian bagi perusahaan. Risiko Bisnis dapat dikategorikan menjadi empat jenis yaitu risiko keuangan, risiko operasional, risiko strategis, dan risiko eksternalitas (Winowod, Sepang, \& Tawas, 2018).

Karakteristik percaya diri dan keberanian dalam mengambil risiko menduduki urutan tertinggi dibanding dengan hal lainnya seperti kepemimpinan, kreativitas, inovasi dan orientasi. Pengambilan risiko sangat membutuhkan kepercayaan diri yang mendalam. Keyakinan akan kemampuan yang semakin besar akan membuat semakin besar keyakinan akan kesanggupan untuk berhasil. Keyakinan akan kesanggupan tersebut membuat semakin besar kesediaan mencoba sesuatu yang justru menurut orang lain dianggap sebagai risiko (Oktavia \& Trimeiningrum, 2018).

Keberanian mengambil keputusan yang barkaitan dengan risiko menjadi modal dalam pengembangan usaha. Perlu persiapan untuk mengantisipasi perubahan lingkungan di masa yang datang untuk bisa membuat keputusan yang efektif. Banyak faktor penentu yang mendorong semangat kewirausahaan. Salah satunya berkaitan dengan kondisi lingkungan seperti ada tidaknya akses modal, ketersediaan informasi dan luas sempitnya jaringan sosial. Hal berikutnya berkaitan dengan ciri kepribadian individu berupa kesadaran akan kebutuhan berprestasi dan efikasi diri. Selanjutnya demografis yaitu perbedaan gender, umur, latar belakang pendidikan dan pengalaman kerja. Ciri pribadi, orientasi pasar dan jaringan kerjasama berpengaruh positif terhadap keberanian dalam pengambilan keputusan. Yang menarik dari penelitian sebelumnya (Rahmawati \& Triyono, 2017), dukungan pemerintah justru berpengaruh negatif sedangkan orientasi pasar positif.

\section{Gender dan Keberanian Mengambil Risiko}

Masyarakat mempunyai stereotype mengenai gender atau jenis kelamin. Lakilaki dan perempuan menurut masyarakat memiliki tingkah laku yang berbeda. Pemikiran dan pola dalam pengambilan keputusan antara laki-laki dan perempuan memiliki perbedaan. Pendekatan yang dipergunakan juga berbeda. Ada kecenderungaan yang berbeda dalam menggunakan perasaan dan logika. Individu lebih feminin memiliki keberanian pengambilan risiko yang tinggi (Arinii, Mangundjaja, \& Hartana, 2010).

Penelitian sebelumnya (Wang \& Wong, 2004) membuktikan bahwa gender berpengaruh terhadap minat berwirausaha. Namun hasil penelitian Arinii et.al. (2010) membuktikan bahwa wanita kurang tertarik pada bidang kewirausahaan, bukan karena menghindari risiko tetapi karena tidak adanya pengetahuan kewirausahaan dan peran sosial tradisional yang melekat.

H1: Terdapat perbedaan keberanian mengambil risiko berdasarkan gender

\section{Latar Belakang Keluarga dan Keberanian Mengambil Risiko}

Keluarga adalah kelompok sosial pertama dalam kehidupan manusia 
dimana anak akan belajar dan mengambangkan dirinya sebagai makhluk sosial melalui interaksinya di dalam keluarga. Orang tua atau keluarga adalah pihak pertama yang mempersiapkan dan menginspirasi anak untuk menjadi pengusaha. Faktor lingkungan keluarga yang mempengaruhi kewirausahaan adalah cara mendidik, hubungan antar anggota keluarga, atmosfir di rumah, kondisi ekonomi keluarga, perhatian orang tua, dan latar belakang budaya (Wiani, Ahman, \& Machmud, 2018).

Kecenderungan mengambil risiko dan kemandirian keluarga menunjukkan niat untuk memulai bisnis sendiri. Pemilihan karir seseorang tidak dapat dilepaskan dari pengaruh kelompok referensinya yaitu lingkungan keluarga dan teman sebaya. Kegagalan dan keberhasilan keluarga dalam memenuhi kebutuhan akan mempengaruhi minat dan pilihan anak untuk memenuhi kebutuhannya di masa yang akan datang. Kelompok referensi berpengaruh positif terhadap intensi berwirausaha. Dukungan dan peran dari orang terdekat, gaya hidup, dan perilaku melihat peluang, dapat mendorong untuk berwirausaha (Afifah, 2018).

Hasil penelitian yang dilakukan oleh Wiani et.al. (2018) dan Wang \& Wong (2004) membuktikan bahwa lingkungan keluarga berpengaruh terhadap minat seesorang untuk berwirausaha. Lebih lanjut, penelitian Arinii et.al. (2010) membuktikan bahwa tidak ada perbedaan antara kelompok yang memiliki tingkah laku pengambilan risiko tinggi dan rendah dalam hal latar status keluarga.

H2: Terdapat perbedaan keberanian mengambil risiko berdasarkan latar belakang keluarga
Pengetahuan Kewirausahaan dan Keberanian Mengambil Risiko

Kewirausahaan berkaitan dengan bakat bawaan. Berkaitan pula dengan urusan lapangan. Kewirausahaan dapat dipelajari dan diajarkan. Belajar menjadi wirausaha dan berperilaku seperti wirausaha dapat dipelajari setiap orang yang memiliki keberanian untuk mengambil keputusan. Kewirausahaan berada pada tataran konsep dan teori bukan intuisi. Prakteknya lebih ke perilaku daripada kepribadian. Keberanisan mengambil risiko dan percaya diri menjadi modal kewirausahaan. Namun perlu ada toleransi risiko yaitu kemampuan dan kreativitas menyelesaikan risiko. Kepercayaan diri yang kuat meningkatkan keyakinan untuk sanggup membuat keputusan. Dampaknya menambah keberanian untuk mencoba pekerjaan yang dinilai berisiko (Mustofa \& Ekawati, 2017).

Pendidikan kewirausahaan memberikan landasan teoritis konsep kewirausahaan. Diperlukan pula untuk membentuk sikap, perilaku, dan pola pikir (mindset) sebagai wirausahawan. Selanjutnya diperlukan untuk mempersiapkan, membangun dan mengembangkan bisnis melalui integrasi antara pengetahuan, keterampilan dan pengalaman (Mustofa \& Ekawati, 2017).

Hasil penelitian Wang dan Wong (2004) membuktikan bahwa pendidikan berpengaruh terhadap minat berwirausaha. Tidak ada perbedaan tingkah laku pengambilan risiko berdasarkan tingkat pendidikan (Arinii et al., 2010).

H3: Terdapat perbedaan keberanian mengambil risiko berdasarkan pengetahuan kewirausahaan 


\section{Operasionalisasi Variabel}

Pengukuran variabel penelitian selengkapnya dapat dilihat pada tabel 1.

\section{Metode Analisis}

Analisis data dilakukan dengan dua pendekatan yaitu Independent Sampel $\mathrm{T}$ Test dan One-Way ANOVA. Independent sampel $\mathrm{T}$ Test digunakan untuk uji beda keberanian mengambil risiko berdasarkan gender dan latar belakang keluarga yang memiliki dua skala. One-way ANOVA digunakan untuk uji beda keberanian mengambil risiko berdasarkan pengetahuan kewirausahaan.

Independen sampel $\mathrm{T}$ test dilakukan melalui dua tahap yaitu menguji kesamaan varian dan menguji kesamaan/beda ratarata variabel. Pengujian kesamaan varian menggunakan Levene's Test for Equality of Variances. Apabila ada perbedaan variance (probabilitas $\mathrm{F}<0,05$ ) maka uji tahap berikutnya menggunakan kategori equal variances not assumed (hasil t-test for Equality of Means) demikian pula sebaliknya. Jika t-test for Equality of Means memiliki probabilitas $t<0,05$ maka kesimpulan akhir terdapat perbedaan atau tidak identik, demikian pula sebaliknya.

One-way ANOVA dilakukan melalui dua tahap yaitu homogenity variance dan ANOVA. Homogenity variance digunakan untuk memastikan terjadi kesamaan varian (homogen) sebagai persyaratan bisa lanjutnya analisis. Homogenitas terjadi jika probabilitas $>0,05$, sebaliknya jika homogenitas tidak terpenuhi maka pengujian tidak dapat dilanjutkan. Jika ANOVA memiliki probabilitas $\mathrm{F}<0,05$ maka kesimpulan akhir terdapat perbedaan atau tidak identik, demikian pula sebaliknya.

Tabel 1. Operasionalisasi Variabel

\begin{tabular}{lll}
\hline \multicolumn{1}{c}{ Variabel } & \multicolumn{1}{c}{ Indikator } & \multicolumn{1}{c}{ Skala } \\
\hline Gender & - Jenis kelamin & Laki atau Perempuan \\
\hline Latar Belakang & - Anggota keluarga berbisnis & - Ada/tidak \\
keluarga & - Penghasilan orang tua & - Diatas atau dibawah 5 juta perbulan \\
& - Asal daerah & - Luar Jawa atau Jawa \\
\hline Pengetahuan & - Jenjang/semester & - Semester 1 - 4, 5 - 8, > 8 \\
kewirausahaam & - Bidang usaha yang diminati & - Kuliner, Fasion, Sembako, Jasa, IT \\
\hline Keberanian & - Keberanian mengambil risiko & Sangat takut (1) sampai sangat berani \\
mengambil risiko & & $(10)$ \\
\hline
\end{tabular}

Sumber: Pengembangan model, 2020

\section{HASIL PENELITIAN}

\section{Responden}

Responden penelitian ini adalah 237 orang mahasiswa fakultas ekonomi dan bisnis di Universitas Pelita Bangsa. Karakteristik responden penelitian dapat dirangkum sebagaimana pada tabel 2 . Responden sebagian besar perempuan, dari keluarga pebisnis, dengan penghasilan dibawah 5 juta perbulan, asal daerah Jawa, kuliah antara semester 5 sampai dengan 8, dalam bidang bisnis kuliner. Pada skala satu sampai dengan sepuluh rata-rata responden cenderung berani mengambil risiko. 
Tabel 2. Data Hasil Kuesioner

\begin{tabular}{lcc}
\hline \multicolumn{1}{c}{ Variabel } & Jumlah & Persen \\
\hline Gender & & \\
Jenis Kelamin: & 129 & 54,4 \\
- Perempuan & 108 & 45,6 \\
- Laki-laki & & \\
\hline Latar belakang keluarga & & \\
Anggota keluarga berbisnis & 149 & 62,9 \\
- Keluarga Pebisnis & 88 & 37,1 \\
- Bukan keluarga pebisnis & & \\
Penghasilan orang tua: & 196 & 82,7 \\
- Dibawah 5 juta/bulan & 41 & 17,3 \\
- Diatas 5 juta/bulan & & \\
Asal daerah: & 200 & 84,4 \\
- Jawa & 37 & 15,6 \\
- Luar Jawa & & \\
\hline Pengetahuan wirausaha & & 35,9 \\
Jenjang kuliah/semester: & 85 & 63,3 \\
- 1 sampai dengan 4 & 150 & 0,8 \\
- 5 sampai dengan 8 & 2 & 49,4 \\
- Lebih dari 8 & & 34,6 \\
Bidang usaha yang diminati: & 117 & 4,2 \\
- Kuliner & 82 & 10,5 \\
- Fashion & 10 & 1,3 \\
- Sembako & 25 & \\
- Jasa & 3 & \\
- Teknologi informasi & & \\
\hline
\end{tabular}

Keberanian mengambil risiko

Skala 1 s.d 10 (Sangat takut 1 s.d berani 10) $\quad 7,0295 \quad$ Cenderung Berani

Sumber: Data penelitian diolah, 2020

\section{Independent-Sample t-Test Gender}

Hasil uji beda keberanian pengambilan risiko berdasarkan gender menggunakan independen sample $t$ test dirangkum pada tabel 3.

Tabel 3. Independent Sample Test Keberanian mengambil risiko berdasarkan gender

\begin{tabular}{|c|c|c|c|c|c|c|c|c|c|}
\hline \multirow{2}{*}{ Variabel } & \multirow{2}{*}{ Kategori } & \multirow{2}{*}{$\mathrm{N}$} & \multirow{2}{*}{ Mean } & \multicolumn{3}{|c|}{$\begin{array}{c}\text { Levene's Test for Equality } \\
\text { of Variances }\end{array}$} & \multicolumn{3}{|c|}{ t-test for Equality of Means } \\
\hline & & & & $\mathrm{F}$ & Sig. & Variance & $t$ & Sig. & Kesimpulan \\
\hline $\begin{array}{l}\text { Jenis } \\
\text { Kelamin }\end{array}$ & $\begin{array}{l}\text { Laki-laki } \\
\text { Perempuan }\end{array}$ & $\begin{array}{l}108 \\
129\end{array}$ & $\begin{array}{l}7,389 \\
6,729\end{array}$ & 2,612 & 0,107 & Equal & 3,027 & 0,003 & $\begin{array}{l}\text { Tidak Identik } \\
\text { (Beda) }\end{array}$ \\
\hline
\end{tabular}

Sumber: Data penelitian diolah, 2020 
Test equality variance pada gender di tabel 3 mendapatkan equal variance assumed dengan nilai $F=2,612$ dan Sig. 0,107 . Sesuai kriteria maka hasil analisis lanjutan yang dipergunakan adalah yang berdasarkan Equal Variance Assumed. Tes equality of mean menghasilkan nila $\mathrm{t}=$ 3,027 dan sig-t sebesar 0,003. Dapat disimpulkan bahwa terdapat perbedaan keberanian mengambil risiko berdasarkan gender. Laki-laki memiliki keberanian mengambil risiko yang lebih besar daripada perempuan. Oleh karena itu, hipotesis pertama penelitian ini terbukti.
Independent-Sample t-Test Latar Belakang Keluarga

Hasil pengujian tabel 4
memperlihatkan variance anggota
keluarga dan asal daerah equal sedangkan
pendapatan tidak equal. Anggota keluarga,
penghasilan orang tua, dan asal daerah
memiliki nilai sig-t lebih besar dari 0,05
sehingga dapat disimpulkan bahwa tidak
terdapat perbedaan keberanian mengambil
risiko berdasarkan latar belakang keluarga.
Oleh karena itu, hipotesis kedua pada
penelitian ini tidak terbukti.

Tabel 4. Independent Sample Test Keberanian mengambil risiko berdasarkan latar belakang keluarga

\begin{tabular}{|c|c|c|c|c|c|c|c|c|c|}
\hline \multirow{2}{*}{ Variabel } & \multirow{2}{*}{ Kategori } & \multirow{2}{*}{$\mathrm{N}$} & \multirow{2}{*}{ Mean } & \multicolumn{3}{|c|}{$\begin{array}{c}\text { Levene's Test for } \\
\text { Equality of Variances }\end{array}$} & \multicolumn{3}{|c|}{ t-test for Equality of Means } \\
\hline & & & & $\mathrm{F}$ & Sig. & Variance & $\mathrm{t}$ & Sig. & Kesimpulan \\
\hline Anggota & Pebisnis & 149 & 7,081 & 1,095 & 0,296 & Equal & 0,600 & 0,549 & Identik \\
\hline Keluarga & Bukan pebisnis & 88 & 6,943 & & & & & & (Tidak Beda) \\
\hline \multirow[t]{2}{*}{ Pendapatan } & $'<5 j t / b l$ & 196 & 6,964 & 7,868 & 0,005 & Not & 1,044 & 0,302 & Identik \\
\hline & '> 5jt/bl & 41 & 7,342 & & & Equal & & & (Tidak Beda) \\
\hline \multirow{2}{*}{\multicolumn{2}{|c|}{$\begin{array}{c}\text { Asal Daerah Luar Jawa } \\
\text { Jawa } \\
\end{array}$}} & 37 & 7,270 & 0,400 & 0,528 & Equal & 0,937 & 0,350 & Identik \\
\hline & & 200 & 6,985 & & & & & & (Tidak Beda) \\
\hline
\end{tabular}

Sumber: Data penelitian diolah, 2020

\section{One-Way ANOVA Pengetahuan Wirausaha}

Pengetahuan wirausaha dan bidang usaha yang diminati menunjukkan hasil identik atau tidak terdapat perbedaan (tabel 5). Analisis one-way ANOVA pada jenjang semester menunjukkan test of homogeneity of variances dengan nilai signifikansi 0,714 lebih besar dari 0,05 dan ANOVA dengan nilai signifikansi 0,177 lebih besar dari 0,05 maka dapat disimpulkan bahwa tidak terdapat perbedaan keberanian mengambil risiko berdasarkan jenjang semester. Hal ini berarti tidak terdapat perbedaan keberanian mengambil risiko berdasarkan pengetahuan wirausaha. Oleh karena itu, hipotesis ketiga pada penelitian ini tidak terbukti.

ANOVA pada bidang usaha menunjukkan test of homogeneity of variances dengan nilai signifikansi 0,241 lebih besar dari 0,05 dan ANOVA dengan nilai signifikansi 0,158 lebih besar dari 0,05 maka dapat disimpulkan bahwa tidak terdapat perbedaan keberanian mengambil risiko berdasarkan bidang usaha yang digeluti. Hal ini semakin menguatkan bahwa tidak terdapat perbedaan keberanian mengambil risiko berdasarkan pengetahuan wirausaha. 
Tabel 5. One Way ANOVA Keberanian mengambil risiko berdasarkan pengetahuan wirausaha

\begin{tabular}{llcccccccc}
\hline \multirow{2}{*}{ Variabel } & \multirow{2}{*}{ Kategori } & $\mathrm{N}$ & Mean & \multicolumn{3}{c}{ Homogenity } & \multicolumn{3}{c}{ ANOVA } \\
\cline { 5 - 9 } & & & & Levene & Sig. & Variance & F & Sig. & Kesimpulan \\
\hline Semester & Semester 1-4 & 85 & 7,224 & 0,337 & 0,714 & Homogen & 1,746 & 0,177 & Identik \\
Kuliah & Semester 5-8 & 150 & 6,900 & & & & & & (Tidak Beda) \\
& Semester $>8$ & 2 & 8,500 & & & & & \\
\hline Bidang & Fashion & 82 & 6,939 & 1,381 & 0,241 & Homogen & 1,670 & 0,158 & Identik \\
Usaha & Kuliner & 117 & 6,932 & & & & & (Tidak Beda) \\
& Sembako & 10 & 7,500 & & & & & \\
& Jasa & 25 & 7,720 & & & & & \\
& IT & 3 & 6,000 & & & & & & \\
\end{tabular}

Sumber: Data penelitian diolah, 2020

\section{PEMBAHASAN}

\section{Keberanian mengambil risiko berdasarkan gender}

Laki-laki lebih berani mengambil risiko daripada perempuan. Pada skala satu sampai sepuluh keberanian laki-laki mengambil risiko sebesar 7,389 sedangkan perempuan 6,729.

Hasil penelitian ini sesuai dengan penelitian yang dilakukan oleh Wang dan Wong (2004). Menurut status sosial tradisional, laki-laki memiliki tanggung jawab mencari nafkah dalam keluarga sehingga akan menghadapi risiko yang lebih besar daripada perempuan.

\section{Keberanian mengambil risiko berdasarkan latar belakang keluarga}

Orang yang berasal dari keluarga yang berprofesi sebagai wirausaha maupun keluarga yang bukan pengusaha memiliki tingkat keberanian mengambil risiko yang sama. Hasil penelitian ini sesuai dengan penelitian yang dilakukan oleh Wang dan Wong (2004). Orang yang berasal dari keluarga dengan penghasilan diatas PTKP maupun dibawah PTKP (penghasilan tidak kena pajak) memiliki tingkat keberanian mengambil risiko yang sama. Hasil penelitian ini sesuai dengan penelitian yang dilakukan oleh Wang dan Wong (2004).

Orang yang berasal dari Jawa dan luar Jawa memiliki tingkat keberanian mengambil risiko yang sama. Hasil penelitian ini sesuai dengan penelitian yang dilakukan oleh Wang dan Wong (2004). Kewirausahaan adalah suatu hal yang dapat dipelajari sehingga semua orang dapat menjadi pengusaha, tidak tergantung pada latar belakang keluarga, penghasilan keluarga, dan daerah asal keluarga tersebut.

\section{Keberanian mengambil risiko berdasarkan pengetahuan wirausaha}

Orang yang memiliki pengetahuan wirausaha yang lebih lama maupun yang baru sebentar memiliki tingkat keberanian mengambil risiko yang sama. Tidak ada perbedaan keberanian mengambil risiko antara yang masih pada semester awal kuliah atau yang sudah di akhir masa kuliah. Demikian pula pada bidang usaha yang bermacam-macam, tidak terdapat perbedaan keberanian mengambil risiko. 
Hasil penelitian ini tidak sesuai dengan penelitian yang dilakukan oleh Wang dan Wong (2004). Dengan adanya perkembangan teknologi informasi, maka memudahkan siapa saja yang akan memulai dan mengembangkan bisnis.

\section{KESIMPULAN}

Laki-laki memiliki keberanian mengambil risiko yang lebih besar daripada perempuan. tidak terdapat perbedaan keberanian mengambil risiko berdasarkan latar belakang keluarga. Ttidak terdapat perbedaan keberanian mengambil risiko berdasarkan pengetahuan wirausaha.

Perlu ditelaah lebih lanjut untuk menguji kembali keberanian pengambilan risiko berdasarkan pengetahuan wirausaha.

\section{DAFTAR PUSTAKA}

Afifah, S. (2018). Pengaruh Perilaku Pengambilan Resiko Dan Kelompok Referensi Terhadap Niat Berwirausaha Mahasiswa Pendidikan Ekonomi STKIP Nurul Huda Kabupaten Oku Timur. UTILITY: Jurnal Ilmiah Pendidikan dan Ekonomi, 2(2), 111-128.

Arinii, R., Mangundjaja, W., \& Hartana, G. T. (2010). Hubungan Peran Jender dan Tingkah Laku Pengambilan Risiko pada Wirausaha Perempuan dengan Usaha Kecil. Mind Set, 1(2), 131-139.

Mulyanto, H. \& Wulandari, A, 2010, Penelitian: Metode $\mathcal{E}$ Analisis. Semarang: CV.Agung.

Mustofa, A. L. A., \& Ekawati, N. W. (2017). KEBERANIAN MENGAMBIL RISIKO MEMEDIASI PENGARUH
EFIKASI DIRI DAN KEBUTUHAN AKAN PRESTASI TERHADAP NIAT BERWIRAUSAHA. E-Jurnal Manajemen Unud, 6(10), 5377-5405.

Oktavia, G. D., \& Trimeiningrum, E. (2018). Pengaruh Percaya Diri Dan Keberanian Mengambil Risiko Terhadap Keberhasilan Usaha Pada Umkm Makanan Ringan Di Kota Semarang (Studi Kasus Pada Sentra Industri Kerupuk, Keripik, Peyek dan Sejenisnya di Kota Semarang). JEMAP : Jurnal Ekonomi, Manajemen, Akuntansi dan Perpajakan, 1(1), 26-40.

Rahmawati, N., \& Triyono, T. (2017). Keberanian dalam Mengambil Keputusan dan Risiko sebagai Karakter Wirausaha Petani Padi Organik di Kabupaten Bantul. AGRARIS: Journal of Agribusiness and Rural Development Research, 3(2). doi:10.18196/agr.3253

Wang, C. K., \& Wong, P.-K. (2004). Entrepreneurial interest of university students in Singapore. Technovation, 24(2), 163-172. doi:10.1016/s01664972(02)00016-0

Wiani, A., Ahman, E., \& Machmud, A. (2018). EFFECT OF FAMILY ENVIRONMENT ON INTEREST IN ENTREPRENEURSHIP STUDENTS SMK IN SUBANG REGENCY. Oikos: Jurnal Kajian Pendidikan Ekonomi dan Ilmu Ekonomi, II(2), 122-132.

Winowod, N. A., Sepang, J. L., \& Tawas, H. N. (2018). PENGARUH INOVASI DAN KEBERANIAN MENGAMBIL RISIKO TERHADAP KINERJA PRODUK DENGAN INTESITAS PERSAINGAN SEBAGAI VARIABEL MODERASI (Studi Kasus Cafe-Cafe di Manado). Jurnal EMBA, 6(4). 
https:/ / www.goodnewsfromindonesia.id /2020/11/03/keren-indonesia-jadisalah-satu-negara-pemilik-startupterbanyak-di-dunia-2020

https://investor.id/it-andtelecommunication/menkominfobanggakan-pertumbuhan-startup-ri https://www.cnnindonesia.com/teknolo gi/20200205204206-206-472064/tren- dan-peluang-industri-e-commercedi-indonesia-2020

https://ekbis.sindonews.com/read/15831 2/34/rasio-wirausaha-di-indonesiatertinggal-dibanding-negaratetangga-1599574154

https://kemenperin.go.id/artikel/19926/ Indonesia-Butuh-4-Juta-WirausahaBaru-untuk-Menjadi-Negara-Maju 